\title{
THE EFFECT OF MARCAINE EPIDURAL ANAESTHESIA ON THE SPINAL CORD INJURED DOG
}

\author{
By S. M. Rezaian, M.D., F.R.C.S. and R. Shams, M.D. \\ Department of Scoliosis and Surgery of Spine, Sina Hopital, \\ University of Tehran, Tehran, Iran
}

Abstract. An attempt by using Marcaine epidural anaesthesia has been made to prevent the central cord necrosis of the spinal cord injured dog. Details of the technique and the results are described.

Key words: Marcaine.

\section{Introduction}

IN a previous experimental work the reserpine, a sympathetic blockage has been successfully used to reduce or prevent the release of catecholamine which its peak up is coincident with the central haemorrhagic cord necrosis in rats (Rezaian et al., 1977). But the resperine for the obvious reason that neither could have clinical indication on the management human spinal cord injury, nor was tolerated by dogs for further investigation. Looking for a suitable drug, Marcaine proved to fulfil most of our aims.

Hirst and Wood (I97I) suggested that procaine diminished the release of acetylcholine by the nerve motor ending. Similarly when procaine is added to the fluid perfusing a ganglion, preganglion fibre stimulation fails to elicit postganglionic discharges and the ganglion cells become insensitive to stimulation by acetylcholine. Furthermore the production of acetylcholine in response to preganglionic stimulation is diminished, showing that procaine has a marked effect on synaptic ending of the preganglionic fibres as well as on the ganglion cells (Murdoch et al., I970). Marcaine has all pharmacological effect of procaine plus twice prolonged action. For these reasons we have used Marcaine epidurally to prevent the secondary sympathetical reaction of postspinal cord injury in dogs.

\section{Material and Method}

Altogether 48 mature mongrel dogs of both sexes, average weight $6.3 \mathrm{~kg}$ were used in this work. Each dog was anaesthetised by iv $0.6 \mathrm{ml} 5$ per cent pentothal per $\mathrm{kg} / \mathrm{w}$ and paralysed by a simple quantitive extra dural pressure (Rezaian, I978). A Foley catheter was introduced into the epidural space by removing ligementum flava $T_{12}-\mathrm{L}$. The catheter pushed upward until its sac laid at the level $T_{10}-T_{11}$. The sac's. tube was connected by a three-way connector to a physiometer and a syringe. By injecting normal saline from the syringe the pressure inside the sac, and consequently on the cord, could be raised as much as necessary. A pressure of $400-420 \mathrm{~mm} \mathrm{Hg}$ was proved to produce incomplete cord injury on the dog (please see detail of technique by S. M. Resaian in another paper).

Dogs alternatively were treated postoperatively and therefore divided into two groups. In group $a$ all were treated by $0.5 \mathrm{ml} 0.5$ per cent of Marcaine per 
kiloweight which injected through the main tube of Foley catheter in epidural space, just before it was to be removed. Dogs in group $b$ were kept for control. Both groups were in similar cages, fed with milk and commercial food. There were 22 dogs in group $a$ and 26 in group $b$.

\section{Observations}

(a) Mortalities. Eight dogs died from group $b$ in the first 24 hours and eight in the subsequent 7 days, due to the spinal cord shock; in a bizarre incontinence paraplegic condition. Whereas in group $a$ only two dogs died-one immediately and one 6 hours after the operation. The remaining dogs had uneventful recovery.

(b) Mobilities. Of the ten dogs remaining in group $b$ all were paralysed with incontinence of urine and faeces. Their general condition gradually deteriorated in IO-I 5 days and had to be sacrificed before they died. Only four of them could be kept beyond 3 weeks. On the other hand in group $a$ all 20 dogs had far better recovery.

Their neurological deficit all improved. Twelve of them were back to normal. Seven of them could use their hind limbs incompletely, but all of them were alive over 3 months in paraparesis condition, only one had urine and faeces incontinence.

(c) Histological Section. Immediately postoperative section of both groups showed equal traumatised reaction with congestion, haemorrhage and oedema of the cord, extending IO-I $5 \mathrm{~mm} \times 6-8 \mathrm{~mm}$. By the end of the first week central necrosis of the cord was obvious in group $b$ but rare area of necrosis could be seen in group $a$ (Figs I and 2). At the end of the third week extensive necrosis was complete in group $b$, whereas some fibrous reaction could be seen in group $a$ (Fig. 3).

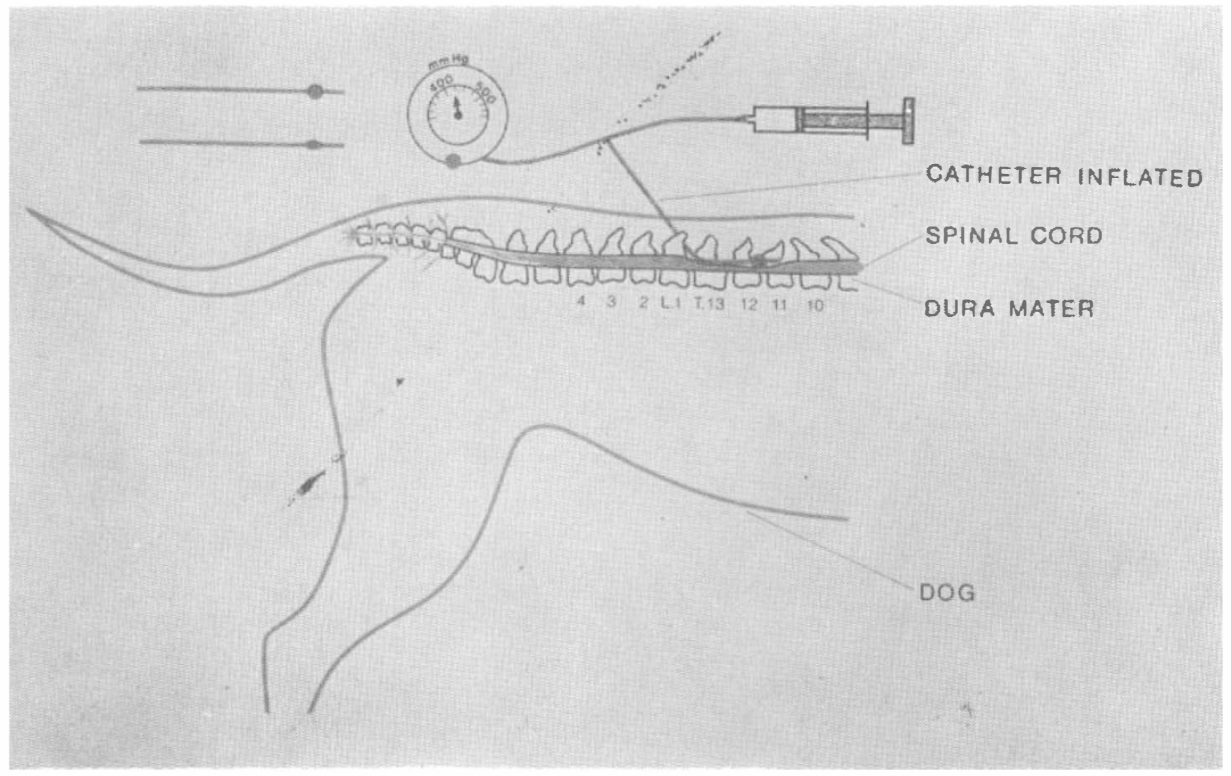

FIG. I

Technique of cord injury. 


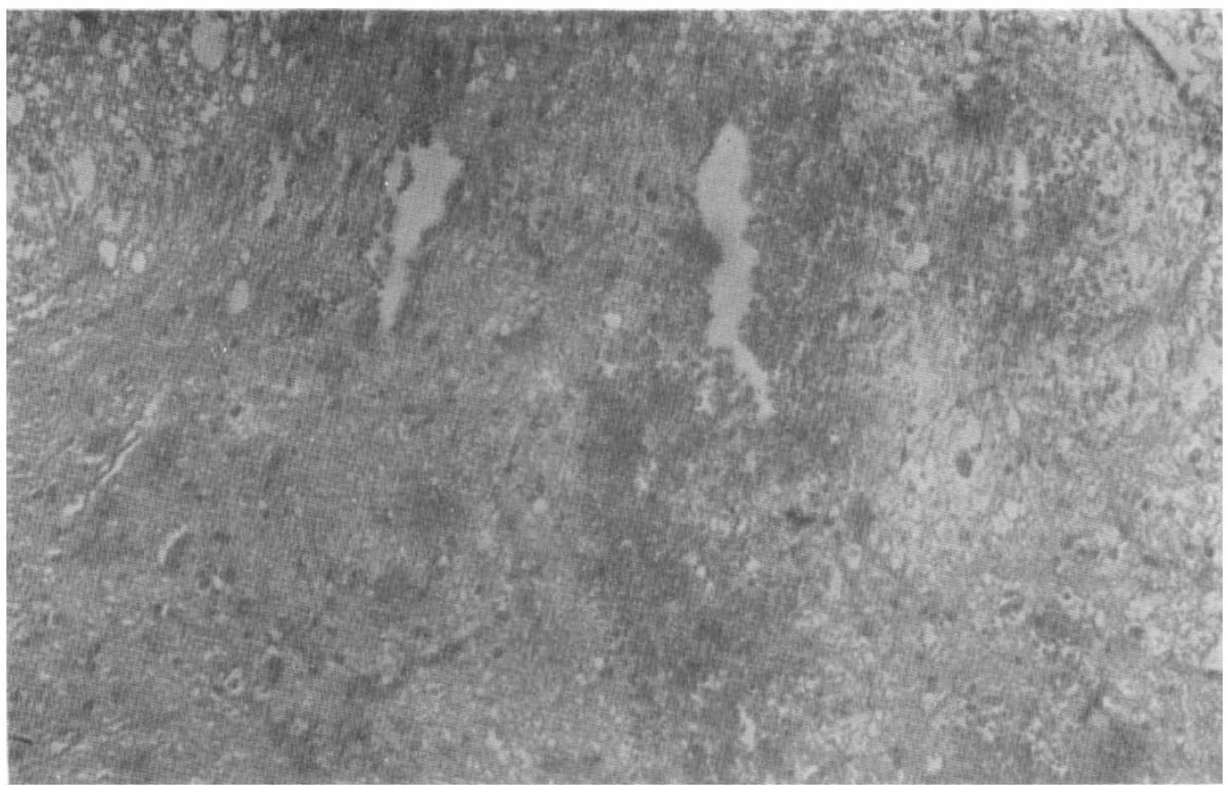

FIG. 2

Dog's cord sections 3 weeks post-injury without treatment.

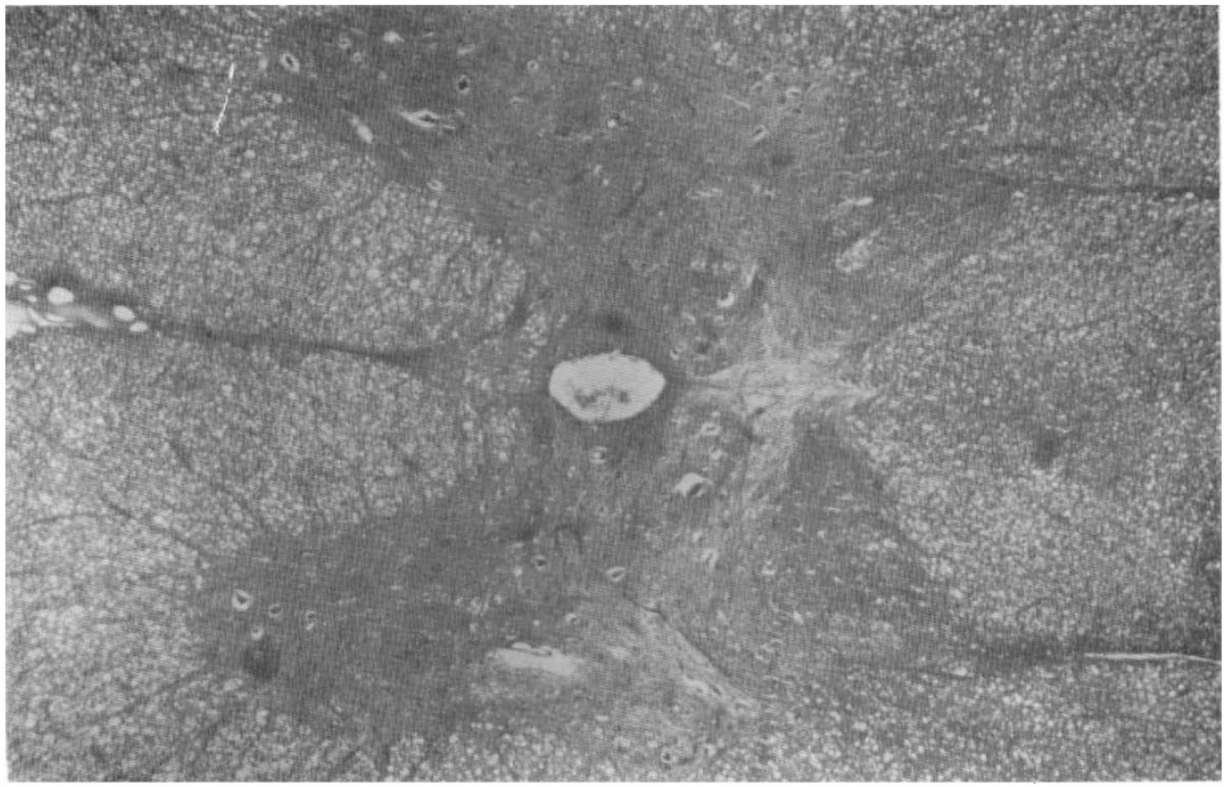

FIG. 3

Dog's cord sections 3 weeks post injury treated with Marcaine. 


\section{Discussion and Conclusion}

A few drugs have recently been successfully used on treatment of spinal cord injured animals. Those included 3-2 bimethyltyrosin (Osterholm et al., 1973), Alphamethyltyrosin (Yeo et al., 1975) and Reserpin (Rezaian et al., I977). Unfortunately these drugs are not suitable for treatment of human spinal cord injury. Whereas in the present experimental work we have used Marcaine-a long-acting local anaesthetic drug which abolishes or diminishes the secondary effect of catacholamine release which is coincidence with the central haemorrhagic necrosis of the cord in dog. This drug probably could be safely used in management of human spinal cord injury.

\section{Summary}

Dogs were paralysed by a simple quantitative pressure technique. A group of them were treated with $0.5 \mathrm{ml}$ of 0.5 per cent of Marcaine epidurally. And a second group were kept untreated for the control. Mortalities in treated group were very much less than the control one. At the same time recovery of neurological deficit were remarkable. Histological section proved the fact.

\section{RÉSUMÉ}

La technique simple á été employee pour 2 groupes de chiens a et b. Qui a provoqeé une paralysie incomplete le groupe 'a' reçu une dose de $5 \mathrm{ml}$ d une solution de 0.5 per cent de marcaine-le groupe ' $b$ ' á été garde comme temion.

La mortalité á été beaucoup moins et la recuperation neurologique en meme temps á été mieux dans le groupe 'a' que le groupe 'b'.

La section histologique également approuveé la difference.

\section{ZUSAMMENFASSUNG}

In zwei Gruppen von Hunden mit einer einfachen Methode wurde Halbseitenlaehmung hevorgerufen. In Gruppe A wurden die Hunde mit $0.5 \% 5 \mathrm{ml}$ Marcaine behandelt. Die Gruppe B wurde ohne Behandlung für Vergleichshunde gehalten.

Todesfaelle in Gruppe A im Vergleich mit Gruppe B waren wesentlich weniger. Die Rueckkehr vom Nervensymptome waren interressar:t.

Histologisch konnte dieser Unterschied ebenfalls gezeigt werden.

Acknowledgement. The authors wish to thank the Ministry of High Education and Science for their financial help and to the Director and staffs of the Department of Pharmacology and Department of Pathology of the University of Tehran for their great technical help for which we owe to all, particularly Dr Khoie for his particular attention to this work and Dr Armin for providing the histological sections.

\section{REFERENCES}

Deguchi, T. \& Narahash, T. (I97I). Effect of procaine on ionic conductions of end plate membranes. F. Pharm. exp. The., 176, 424-433.

HolmDAHL, M. H., SJORGREN, S., STROM, G. \& WRIGHT, B. (I972). Clinical aspect of continuous epidural blockade for post operative pain relief. Uppsala F. Med. Sci., 77, 47-56.

MuRdoch, J., Ritchie \& CohEN, P. J. (1970). Cocain, procaine and other synthetic local anesthetics in the pharm. of therapeutic, by Gilman \& Goodman. 5th ed., pp. 379.

Narahashi, T. \& Frazier, D. T. (I968). Site of action and active form of local anaesthesia in nerve fibres. Fedn. Pro., Fedn. Am. Socs. exp. Biol., 27, 408. 
OSTERHOLM, J. L. \& MATHEws, G. S. (1972). Altered norepinephrine metabolism following spinal cord injury in relationship to haemorrhagic necrosis and post wounding neurological deficit. F. Neurosurgery, 36, 386.

Rezaian, S. M., Rezuani, M., Movlavi, M. \& Daneshbod, A. (1977). The effect of medical sympathetic blockade (using resperine) in the management of spinal cord injury. F. Paraplegia, 15, I72-1 75. 